\title{
A REVIEW OF THE SEISMIC RESISTANCE OF PRESTRESSED CONCRETE
}

\author{
R. W. G. Blakeley*, R. Park**, and R. Shepherd ${ }^{+}$
}

\section{Introduction}

The use of prestressed concrete components has been accepted for many years for structures under gravity loading. The applications of the material are increasing rapidly, encouraged by such advantages as the possibility of pleasing architectural forms, and the suitability of prestressed concrete to modern prefabricated construction. However the use of prestressed concrete in primary seismic resistant elements such as shear walls and frames has created considerable controversy. This review is a historical trace of the approach of design and research engineers to the suitability or otherwise of prestressed concrete for earthquake resistance. It discusses such fundamental properties as stiffness, damping, energy absorption and dissipation, and ductility, all of which will affect the response and hence the structural behaviour of prestressed concrete buildings under earthquake loading.

\section{The Beginnings: Dynamic Loading of Prestressed}

The first dynamic load tests carried out on prestressed concrete were conducted by E. Freyssinet in 1934, when he fatigue tested two telegraph posts, $16 \mathrm{~m}$. long, with similar ultimate loads, one being prestressed concrete and the other reinforced concrete. In the fatigue tests the maximum load was $50 \%$ of the static ultimate load and the load was completely reversed during each cycle. It is reported that the reinforced concrete post had failed after "a few thousand cycles" whereas the prestressed post was still in good condition after 500,000 cycles. This type of test involving a direct comparison of a prestressed component with an equivalent reinforced component, was common in tests carried out in the early development stages of prestressed concrete. Since Freyssinet's initial test a large number of fatigue tests have been carried out on prestressed concrete members. This research into the fatigue characteristics of prestressed concrete has been extensively reviewed by Hunt26(1966) and Jacobs $29(1968)$. Consequently in this review only those fatiguetype tests which directly aid understanding of the seismic behaviour of prestressed concrete structures will be discussed.

\footnotetext{
*Graduate Student, **Professor, +Reader, Department of Civil Engineering, University of Canterbury, New Zealand.
} 


\section{First Uses of Prestressed Concrete in Primary Seismic Resistance Elements}

Ellison and Lin (1955) 14 and Engineering News Record (1955)66 reported the construction of a 9-storey car parking building in San Francisco, in which the key element in resisting seismic forces was a prestressed concrete shear wall near one corner. Preliminary calculations had indicated that most of the deflection of the shear wall under lateral forces would be caused by bending in the lower portion. Hence it was felt that the deflection could be reduced at low cost if only the bottom $40 \mathrm{ft}$. of the shear wall was prestressed. The amount of prestress required was determined by the condition that no tensile stress would be created in the shear wall under seismic loading, determined from equivalent lateral loading specified in the San Francisco Code on the basis of a $6 \%$ seismic coefficient. It is interesting to note that tendons were not bonded to concrete because a factor of safety of 1.65 against cracking was deemed to justify this. At this stage in development the importance of availability of post elastic deformations, which subsequent research demonstrated, was not considered. In a later paper Lin (1962)37 made a good case for the advantages of prestressed concrete shear walls on elastic consideration alone.

In a paper presented to the World Conference on Prestressed Concrete, 1957, Ban4 commented that in Europe studies to obtain a reasonable building frame appropriate for prestressed concrete structures had been undertaken, and several multi-storeyed office buildings had been completed there. The frames were composed of reinforced concrete columns and prestressed concrete beams. Ban went on to say that the prestressed concrete structures encountered were mainly built up with pre-cast members, the joints of which were considered to be simply supported or hinged. However he advocated rigid connection between the beams and the columns in order to resist lateral load. One method of framing multi-storied buildings was to assemble prestressed concrete beams and reinforced concrete columns with a reinforced concrete joint. Ban introduced his own proposals for extending the prestressing cable through to the column and hence placing the whole joint in compression. His scheme was the forerunner of modern precast prestressed beam column connection details.

In another paper presented at the San Francisco World Conference on Prestressed Concrete (1957) Spooner and Norman 55 discussed the design of prestressed concrete bridges for seismic resistance. Special attention was paid in New Zealand to ensuring that simply supported spans were adequately anchored down and further that in multi-span structures the individual spans were linked together by special means.

\section{The Development of a Philosophy of Seismic Design for Prestressed Concrete}

In the early 1960's a philosophy of seismic design of concrete structures came to be accepted. Design requirements were that under a moderate earthquake such as may be expected several times during a structure's life, it should survive without damage, and that it should survive without major structural damage in the most severe probable earthquake expected during its life. A further condition is 
that the structure should not collapse even under earthquake loading of an abnormal intensity.

However authorities differed as to the ability of prestressed concrete structures to fulfil these requirements. While Lin (1962) 37 was enthusiastic about its suitability, Glogau (1963) 21 commented, "In view of the ductility required to reduce the response, caution is advocated by such authorities as Prof. Tanabashi and Prof. Penzien, and Mr Steinbrugge."

The publication of Lin's (1964)38 paper was a stimulus to the debate. He discussed several important aspects of seismic design of prestressed concrete structures. He discussed the special case of allowable stresses and load factors for prestressed concrete. He showed that for a working stress design method it was appropriate to take three quarters of all moments, loads, and shears from seismic loading, and then use normal working stresses. This approach was equivalent to the normal $331 / 3 \%$ allowable stress increase for seismic loading. He also considered the ultimate strength method and showed that load factors stated in codes were consistent with the one-third decrease allowed in static load values under dynamic conditions.

The results of some tests studying the energy absorption capacity of prestressed concrete members were presented. Iin noted that this energy absorption capacity was important if structures were to withstand heavy earthquakes. Moment-rotation curves were plotted for tests to failure of prestressed concrete beams in bending. The large area beneath the curves was taken to be indicative of high available energy absorption.

of particular interest in the paper was the result of a dynamic computer analysis of a 19-storey prestressed concrete apartment building. The building was first designed using the earthquake forces specified by the 1961 Uniform Building Code. The dynamic response of the structure to the North South component of the 1940 El Centro earthquake was calculated by a digital computer assuming linearelastic behaviour. Comparison of the static and dynamic displacements obtained by Lin are shown in Fig. 1 . The fact that the El Centro earthquake produced forces and displacements about five times the code values emphasised the need for prestressed structures to be capable of developing large post elastic deformations if they were to be able to survive major earthquakes.

In discussing Lin's paper Rosenbleuth (1966)49 warned against establishing conclusions based only on the curve for first loading. He illustrated the significance of the shape of the unloading forcedeformation curves using the two diagrams in Fig. 2. Respectively, they represent a nonlinear elastic system and a classical elastoplastic one, both having the same force-deformation curve for critical loading. He showed that the two types of structures considered although characterized by the same force-deformation curve on first loading, could undergo, on the average, maximum loads for a given deformation or maximum deformations for a given load, that were approximately $\sqrt{\mu}$ times greater for type $A$ than for type $B$ (where $\mu=$ the ductility factor as defined in Fig. 2). This theory was dependent on a hyperbolic design acceleration spectrum in the range 


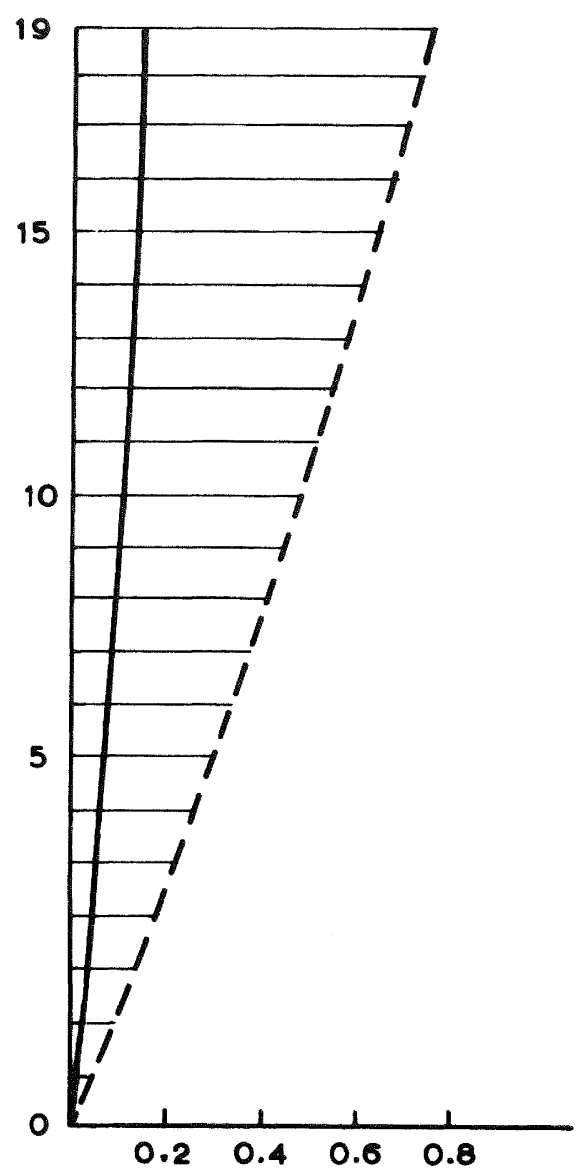

DISPLACEMENTS (Feet)

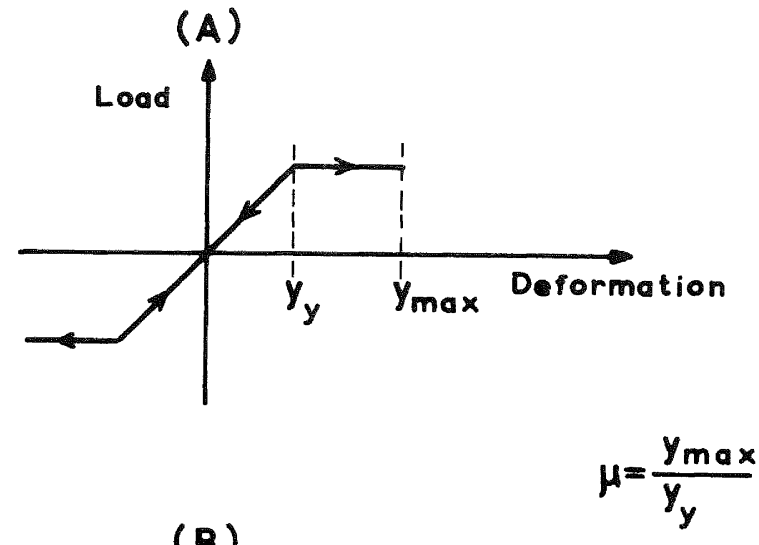

(B)

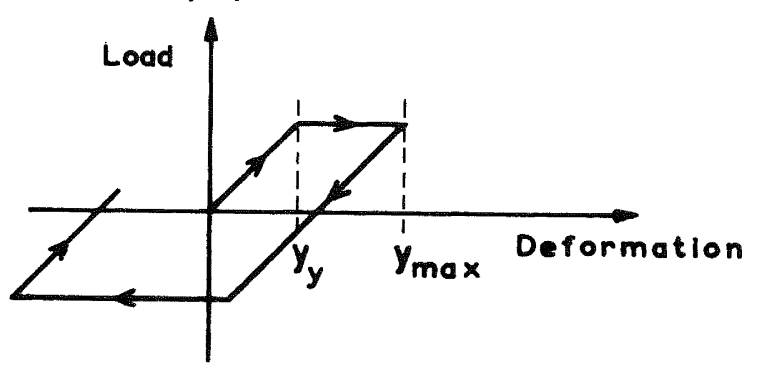

Fig. 2.

EL CENTRO 1940 EARTHQUAKE.

code static VALUEs.

Fig. 1 .

of interest. For a ductility factor of 3 this meant $73 \%$ greater stresses or deformations, and for $\mu=5$ it meant an increase of $124 \%$. Rosenbleuth did not contend that prestressed concrete structures could be idealized as of type A, but felt that the shape of their force deformation curves relative to their reinforced concrete counterparts and their lower damping characteristics, meant that for a comparable mass and stiffness a prestressed structure was likely to give greater deformations or be called to resist higher forces, than a reinforced concrete structure, under most types of strong earthquakes. He noted that to resist a given set of forces, a prestressed structure normally was considerably more flexible than its reinforced counterpart. This flexibility was a desirable feature for seismic loading resistance, and partly counteracted the effect of smaller energy dissipation capacity under cyclic loading.

It is worth noting at this point that the above theory is further amplified in a book shortly to be published by Newmark and Rosenbleuth. A comparison is presented of the two single degree of freedom systems discussed above with the same mass, same initial stiffness, and both having a coefficient of critical damping of $2 \%$. 
The solution of the expression obtained shows that if the deformation of the two systems takes them to the same ductility factor the forces in the elastic bilinear system will be 1.4 times those in the elastoplastic system. Alternatively if the forces imposed on the two systems are the same the ductility factor requirements of the elastic bilinear system will be 1.3 times those of the elasto-plastic system.

The ratios represent an upper limit for the relationship of loads and ductilities between prestressed concrete and reinforced concrete. The actual situation will be affected by; the fact that prestressed concrete will have a greater initial stiffness than reinforced concrete because of cracking in the latter, the inclined rather than horizontal upper part of the linear curve for prestressed concrete, and the hysteretic damping actually present in prestressed concrete (although Rosenbleuth has taken this into consideration by saying that the prestressed structure's initial percentage damping is likely to be smaller than the $2 \%$ critical assumed).

\section{Observations of Behaviour of Prestressed Concrete under Actual Earthquakes}

5.1 Skopje, 1963. Several buildings in Skopje incorporated prestressing in some elements. Berg ${ }^{7}$ reported one case of structural damage amongst the prestressed buildings. One of the shop buildings at the new Skopje steel works was a precast, prestressed concrete structure consisting of precast roof construction on continuous prestressed concrete columns. The columns were I-shaped and pretensioned. The earthquake caused the building to rock on the columns in the direction of the girders. This induced severe bending moments at the top and bottom of each flange in the weak direction of bending, resulting in crushed concrete at the toes of the flanges. The prestress in the flanges was thus destroyed, and while the columns could be readily repaired to restore their vertical load carrying capacity, the prestress could not be restored and hence the stiffness under lateral loadings would be reduced because of earlier cracking. Therefore an auxiliary bracing system had to be provided if the structure was to have the ability to resist horizontal forces in the longitudinal direction.

5.2 Alaska, 1964. Kunze et al33 reported that of some 28 structures in Anchorage employing precast, prestressed elements, five suffered partial or total collapse. Of these, two were still under construction and, as a consequence, had not yet been tied together to resist an earthquake force. A sixth structure involving posttensioned lift-slab construction also collapsed. However there appear to have been no failures of the prestressed concrete members themselves. In nearly every case the supporting structure, which was built of traditional materials collapsed or connections were ineffective. Even the controversial failure of the Four Seasons Apartment Building appears to have been due to a bond failure at a splice in the mild steel reinforcement of the concrete shear walis, rather than a failure of the unbonded 8-inch prestressed slab.

Sutherland 56 observed 13 structures incorporating prestressing which suffered no damage other than very minor cracking of the blockwork. Included in these were two buildings using prestressed concrete tees and columns as frames. 
5.3 Niigata, Japan, 1964. Sutherland56 reported on a study of the three structures in Niigata incorporating prestressing to any material degree. Two were bridges and in both cases the prestressed members were not damaged, despite considerable settlement and displacement of the foundations of the abutments.

The third structure, the railway station, had an entire canopy over the foyer of post tensioned precast members on precast columns and beams assembled with mortar joints and grouted post-tensioned cables. Although the foundation material appeared to have subsided by two feet, the structure itself had withstood the movement exceedingly well.

5.4 Caracas, 1968. Fintel19 reported on the behaviour of structures in the earthquake. No prestressed concrete structures were in the area of high damage and none of the 12 structures in Caracas with significant amounts of prestressing were affected.

\section{Test Members Under Reversed Cycles of Loading}

Penzien (1962)48 carried out a series of tests on model prestressed concrete beams of dimensions 6" $\times 6 " \times 90 "$. He set out to determine damping characteristics of prestressed concrete using both steady state and transient vibrations. He measured values of damping of less than 1\% critical viscous damping for beams in which no cracks were present. Upon the development of even microscopic tension cracks the value could be expected to rise to the order of $2 \%$ of critical. The previous history of loading was seen to be an important factor, especially when large dynamic loads had been applied, and the beam had been loaded well into the cracking range. Damping from 3 to $6 \%$ of critical was present after cracking.

Nakano (1964)41 examined the behaviour of prestressed concrete portal frames under lateral force. His test specimens consisted of three prestressed concrete portal frames, $0.9 \mathrm{~m}$. in height and $2.6 \mathrm{~m}$. in span, which were loaded horizontally. The ratio of rigidity of the precast beams to the columns was made as close as possible to that of existing prestressed concrete buildings. Resistance against lateral force, ductility, and dynamic characteristics were studied. The lateral loads the frames sustained at failure were 1.52, 1.92, and 1.94 times the elastic design horizontal loads based on first cracking. Specimen No. 1, which was ungrouted, showed a decreased resistance to horizontal load of approximately 24 per cent, when compared with the grouted specimens.

The ratio of maximum horizontal deflection to the measured deflection corresponding to the design force, was found to be 9 for frame No. 1 and for frames Nos. 2 and 3 was 12.5.

A limited number of alternating loads were applied to the frames at a loading rate of one cycle for 52 seconds. Fig. 4 shows load-deflection curves obtained. Significant area within the hysteresis loops was only obtained once load was taken close to the maximum resistance of the member.

The vibrating characteristics of the frame under horizontal impact loading were also studied. Percentage of critical damping 
was found to be $4 \%$ and $8 \%$ respectively after loading just beyond elastic design load and after the final loading.

Nakano concluded from these tests that the ultimate strength design method is applicable for prestressed concrete portal frames, that deviation of deflection characteristics under repeated loading is not considerable, that ample ductilities are guaranteed, and that increment of period of natural vibration and of critical damping with increment of load is small.

Further research was carried out at the Japanese Building Research Institute, Ministry of Construction, on lateral loading of a four storeyed model structure in prestressed concrete. These tests by Nakano (1964)42 set out to clarify load deflection characteristics of prestressed concrete building structures. The model consisted of a rectangular structural frame 4.2 metres high and 2.7 times 2.6 metres in plan, supporting four slab floors. It was tested by applying alternating cycles of horizontal static load to each floor level.

The load deflection diagrams plotted for each floor showed no sharp changes in stiffness at cracking and the stiffness of the frame reduced continuously with increase of load. Recovery of deflection was good and consequently energy absorption by plasticity had been relatively small. Values of percentage of critical damping were calculated for each storey. Typical results were a variation of 3\% to $7 \%$ over increasing loading stages in the test, at the first storey. Nakano warned that special attention should be paid to the seismic response of prestressed concrete structures because of their different dynamic characteristics to reinforced concrete structures. The main point of difference is the degree of inelastic deformations suffered by comparable prestressed and reinforced concrete structures under a lateral load greater than the design force. Because the function of critical damping is smaller for prestressed concrete structures than for reinforced concrete structures it is generally assumed that the prestressed structure will be subjected to a greater seismic force. Hence it may be considered that the equivalent static lateral force, corresponding to the same ground motion should be greater for prestressed concrete structures than for reinforced concrete structures. This means that adequate ductility must be provided for and possible large deflections of the structure must be considered. Nakano drew attention to the proper design of panel joints and the avoidance of premature plastic hinge formation in columns if ductility is to be assured.

Experiments have been carried out to determine the validity of using static cyclic loading such as was used by Nakano on the four storey model, for representing the effect of relatively rapid vibrations such as would be experienced in an earthquake. Oladapo (1964)46 described tests to investigate the effects of the rate of loading on the moment rotation of prestressed concrete beams. The effect of the rate of loading was to displace the moment-curvature relation upwards as the rate of loading increased. This was due to the time dependent effects of creep on the deformation of concrete. A typical test by oladapo compared loading to failure of identical prestressed concrete model beams over time periods of 1 second and of 40 minutes. For the dynamically loaded beam moments were greater than in the statically loaded beam by $9 \%$ at the elastic limit and 
by 7\% at rupture. There were also corresponding increases in flexural stiffness; the rotation at cracking was reduced in the dynamic case. Thus static cyclic loading tests would appear to give slightly conservative results, as under dynamic loading the probably greater response of the structure, due to apparent greater stiffness, would be more than offset by the apparent greater strength.

Later tests by Spencer (1966)52 involved cyclic loading tests to measure stiffness and damping properties of prestressed concrete members. End rotations were applied which varied about a mean of zero with frequencies of 0.5 to $2.0 \mathrm{c} . \mathrm{p} . \mathrm{s}$. , and which produced either uniform shear or uniform moment loading up to failure. Stiffness and damping values were found to be dependent on the type of loading, but were independent of frequency and the number of cycles applied.

Recent research by Inomata (1969) 28 involved a comparative study of prestressed and reinforced concrete beams subjected to reversed loading. The beams were of rectangular section with a stub at midspan giving a simulated beam-column connection. Span length was $8^{\prime}-6^{\prime \prime}$. A static cyclic loading was applied. To make a comparison between the behaviour of prestressed concrete beams and that of reinforced concrete beams under reversed loading two cases were studied; (a) beams with the same ultimate failure strength, (b) beams with the same working strength. In both cases the factors of safety against failure at working stress were higher for prestressed concrete than for reinforced concrete. Mean values obtained from tests of case (a) above were that the safety factor against failure for reinforced concrete beams was 2.4, while that for prestressed concrete beams was 3.5 .

Inomata recommended that to provide adequate ductility and reduce excessive loss of stiffness, the ultimate limit load of a prestressed concrete member should be calculated in accordance with the F.I.P. - C.E.B. recommendations 17 . In these recommendations the flexural ultimate limit strength should be calculated using the design strength of the material and limiting possible steel elongation to less than 1\%. Inomata calculated values of ductility factor being the ratio of the measured deflection under the maximum measured load to that of the limit load. The ductility factors so obtained varied from 3.8 to 5.7 for prestressed members which Inomata felt to be sufficient comparable to the reinforced members.

The significance of the ductility which has been shown to be available in this sort of cyclic loading test is dependent on the actual ductility requirements of prestressed concrete structures under earthquake loading. More research is required on dynamic analyses of structures before this can be stated with confidence.

\section{Third World Conference on Earthquake Engineering, 1965}

One of the most important topics discussed during the papers on prestressed concrete at this conference was that of Energy Absorption. Guyon 22 stated that "neither theoretically nor experimentally is the energy absorption at failure for the same cross section, the same concrete and the same ultimate moment, smaller for prestressed concrete than for reinforced concrete." Despeyroux ${ }^{12}$ illustrated this same point as shown in Fig. 3. The energy stored 

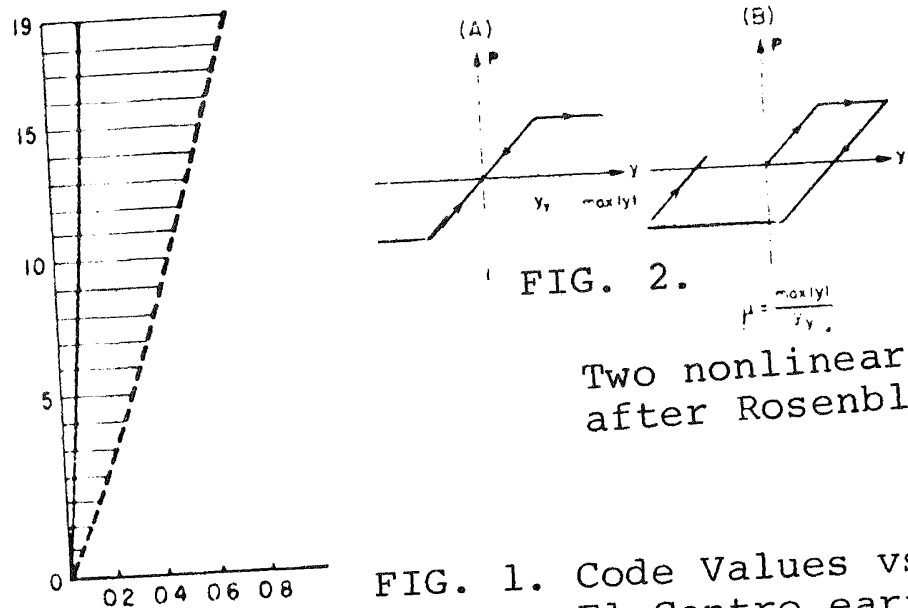

nonlinear systems nonlinear systems 49

FIG 1. Code Values vs.

El Centro earthquake, after $\operatorname{Lin}^{38}$.

(0) DISPLACEMENTS, FT

EL CENTRC $19 \triangle 0$ EARTHQUAKE

CODE STATIC VALUES

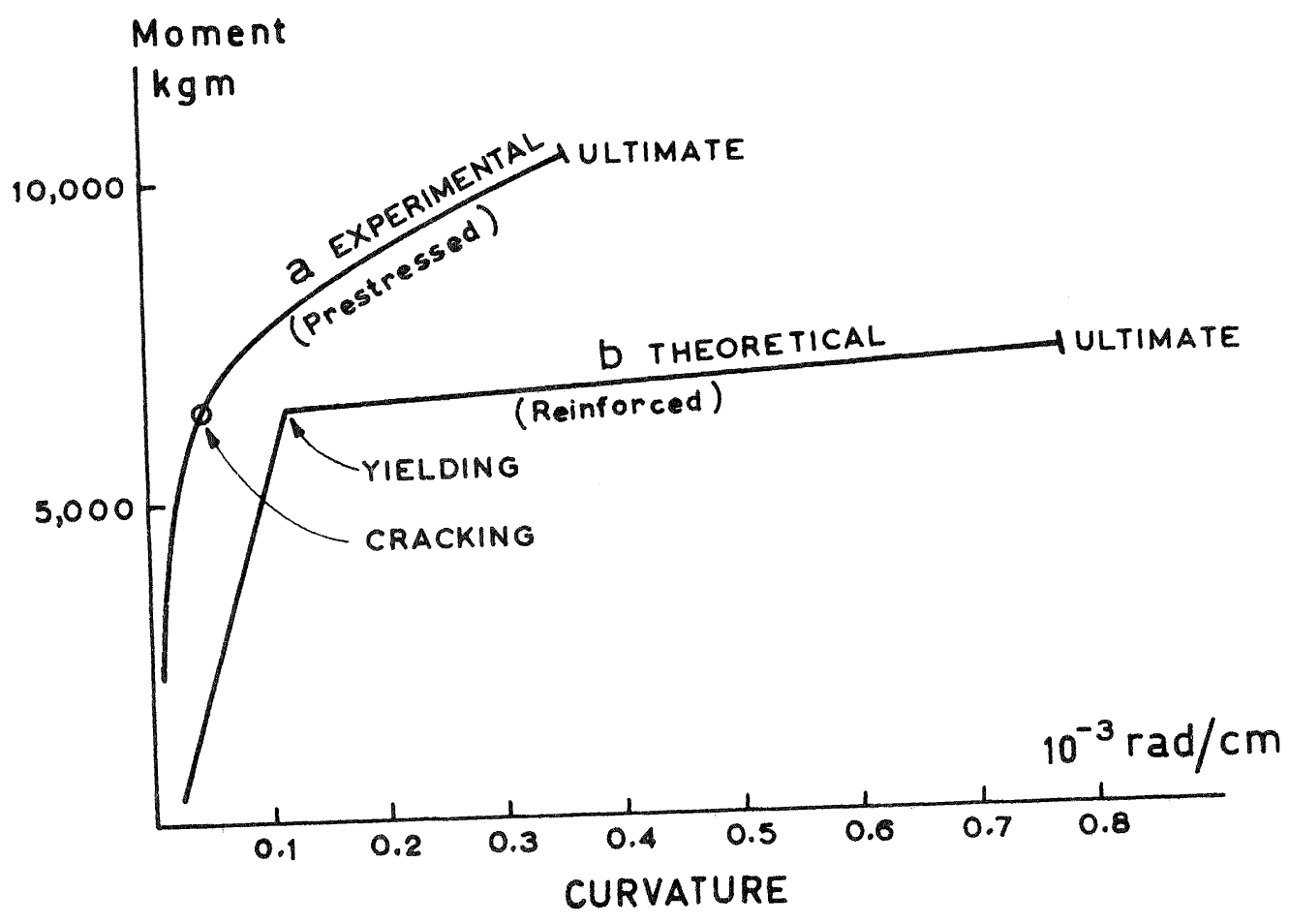

FIG. 3. Energy absorption considerations, after Despeyroux 12 .

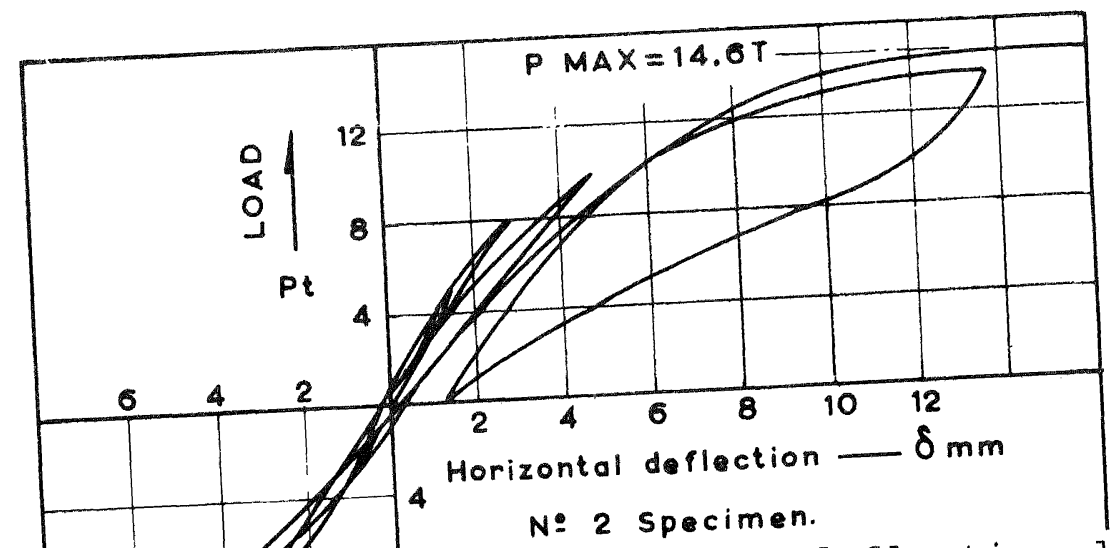

$N: 2$ specimen

FIG. 4. Load-deflection diagr: under cyclic loading. after Nakano 41 .

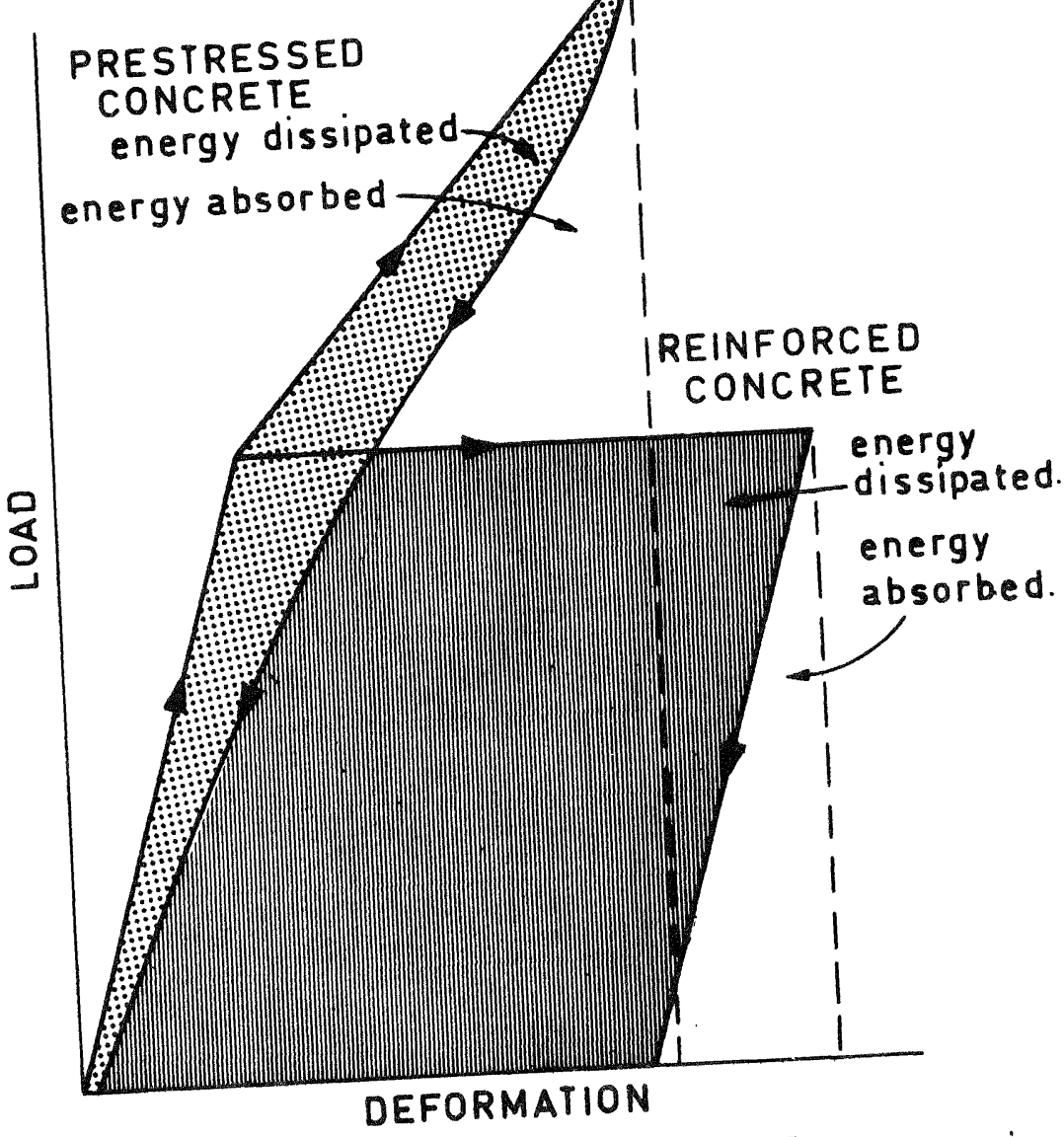

FIG. 5. Dissipation of energy in PSC and RC members, after Candy 12 
per unit of length can be written as the product of moment and curvature and hence the areas under the curves for prestressed concrete and reinforced concrete give an indication of their energy absorption capacities. He concluded that there was no reason for the area under the curve for prestressed concrete to be systematically smaller than that for reinforced concrete and could in fact be the contrary.

However the critical factor affecting the response of a structure under earthquake acceleration cycles is not the energy absorption capacity of its members but rather their energy dissipation characteristics. In the discussion of Despeyroux's paper C.F. Candy illustrated this point with Fig. 5. Repetitive loading tests have given curves for the two materials approximately as drawn. The shaded area represented the energy dissipation; the area up to the dotted line represented the energy absorbed. Thus although the energy absorbed by a prestressed member and a reinforced concrete member may be the same, very much more energy would be dissipated in the latter member and thus the response of the latter to an earthquake must be smaller. He concluded that the reduction in response caused by plastic strain is much smaller in prestressed concrete.

Sutherland ${ }^{56}$ and Nakano 42 also presented papers on the seismic resistance of prestressed concrete, which have been discussed elsewhere in this review. Zavriev62 reported some large scale investigation of seismic behaviour of prestressed concrete bridges in the Soviet Union. He felt that the use of prestressed concrete in seismic resistance structures was expedient. Under moderate earthquakes the resistance to plastic deformations would result in little damage to structures and he felt that under heavy earthquakes the behaviour of prestressed concrete sections would be similar to that of reinforced sections, thus eliminating the characteristics of prestressed concrete which increase dynamic loads.

\section{Fifth Congress of La Federation Internationale De La Precontrainte, 1966}

Several papers presented to the Congress relating to seismic resistance of prestressed concrete are of interest. Hognestad 2. reporting on research on prestressed concrete outside of Europe and U.S.S.R., listed the three principle subjects of research as being fire resistance, earthquake effects, anu side effects of these two. He commented on the importance of jointing of prestressed precast elements under seismic conditions and felt that the study of this question had been relatively neglected. Ligtenberg ${ }^{35}$ reported on research on prestressed concrete in Eastern Europe but made no mention of seismic investigations. Gvodzev 24 reported on research on prestressed concrete in U.S.S.R. and neighbouring countries. Considerable attention had been given to fatigue loading but tnere was no mention of seismic research.

Reports to the Congress on the general principles of seismic design will be included in the next section. 


\section{Principles and Recommendations for Seismic Design of Prestressed Concrete}

The Seismic Commission of the F.I.P. ${ }^{18}$ presented its report to the Fifth Congress, 1966, on "General Principles of Earthquake Resistant Design of Prestressed Concrete Structures". The Commission found that much theoretical and experimental research was still required in order to prepare an international code of practice. To provide immediate assistance to designers, provisional regulations dealt with the main aspects of seismic design and construction :

Consideration of regional and local conditions - seismological conditions, construction techniques, construction costs, must be considered when establishing design criteria.

Degree of damage to structure - based on economic considerations but minimum requirement is prevention of loss of human life.

Safety of Structures - consider stresses and strains, deformations, modes of failure. Safety factors should be not less than those of traditional structures.

General Planning - attention to symmetry if possible, foundation conditions, joints and supports.

Seismic Analysis - equivalent static loads acceptable. Dynamic computer analysis is recommended.

Method of Structural Design - ultimate strength or working stress is acceptable.

The P.C.I. (1966) 65 have also presented "Principles of the Design and Construction of Earthquake Resistant Prestressed Concrete structures". The recommendations allow for design by either elastic theory using chapter 26 ACI 318-63 with a 25\% reduction of all moments, shears and loads in place of the normal $1 / 3$ stress increase, or ultimate strength theory provided the service load deformations are checked. Special attention is devoted to connections.

N.Z.P.C.I. (1966) 64 published their "Seismic Design Recommendations for Prestressed Concrete". The ultimate strength design method was recommended and minimum load factors were suggested. Other recommendations were that all prestressing tendons should be fully grouted throughout their length and that where structures incorporate mortar joints suitable binding, or enclosure of the joint itself, should be provided to prevent loss of material.

\section{Response Analysis of Prestressed Concrete Frame Structures}

Spencer (1968) 54 studied the non-linear dynamic responses of two reinforced and six prestressed concrete versions of a twenty storey framed structure to a strong earthquake. An idealized non 
linear moment rotation hysteresis loop for the prestressed concrete was used in the analysis. The effects of different member properties, different amounts of hysteretic damping, and two different viscous damping mechanisms on response and energy dissipation were compared. The excitation used in each analysis was the first 8 seconds of the accelerogram of the EI Centro, 1940 earthquake. The prestressed concrete structures had higher lateral displacements and interstorey drifts than the comparable reinforced concrete structures. However the ductility requirements of the prestressed concrete were markedly lower. The maximum ductility factor for the girder hinge (being the ratio of maximum rotation to rotation at first cracking) for the prestressed frames was 5.4 compared to that of 16.8 for the reinforced concrete frames. Spencer explained this apparently surprising result by saying that the difference was partly due to the greater hinge length assumed for the prestressed members. He felt that since prestressing delays the development of curvature concentration due to yielding these values of ductility factor would give an indication of the relative amounts of concrete distress to be expected within prestressed and reinforced concrete hinges.

This paper was a significant beginning to the non linear response analysis of prestressed concrete structures. From this study it appears that a prestressed concrete structure similar to that analysed could be designed to withstand a strong earthquake. There would apparently be no structural damage to the prestressed concrete members, but non structural damage arising from greater interstorey drifts may be greater than with a reinforced concrete frame.

The accuracy of the results obtained was very dependent upon factors such as:

(a) the correct representation of damping;

(b) whether the analysis technique of taking the same stiffness for the prestressed concrete as for the reinforced concrete members is reasonable;

(c) the correct assumption of plastic hinge lengths.

These questions will only become clearer as more such analyses are carried out.

\section{Current Research}

Only three current research projects on the seismic behaviour of prestressed concrete were known of at the time of writing this report. 
Dr K. Nakano, of the Building Research Institute, Japan, has recently been carrying out lateral load tests on a three-quarters size model structure. The structure was designed to form plastic hinges in the beams rather than in the columns.

Dr R.A. Spencer, Assistant Professor, University of British Columbia is at present working on two projects both of which are in their initial stages. One is a nonlinear dynamic analysis, similar to that described at the Fourth World Conference on Earthquake Engineering, but with a revised representation of the interfloor damping. The other is an experimental programme, the details of which have yet to be finalised. The performance of various types of joint between beam and column may be investigated.

At the present time at the University of Canterbury a testing programme on full size precast prestressed beam-column assemblies is nearly complete. The units have been subjected to high intensity cyclic loading with a view to determining ductility, energy dissipation, and stiffness degradation properties of the prestressed members. Further work is to be carried out in an analytical method for computing the moment-rotation curves found experimentally, and in the use of such moment-rotation curves or their idealizations in dynamic computer analyses of prestressed frame structures.

\section{Summary}

The following points have emerged of immediate relevance to seismic design of prestressed concrete.

(a) Damping. The internal damping of prestressed concrete has been generally accepted to be lower than that of reinforced concrete structures. The percentage of critical damping appears to be 1-2\% before cracking of the member and $3-6 \%$ after cracking. Percentage of critical damping for reinforced concrete is often taken to be $8 \%$.

(b) Ductility. Cyclic loading tests have indicated that quite large ductility factors can be achieved with concrete members. However the actual ductility requirements of prestressed elements under seismic loading have not yet been conclusively determined.

(c) Energy Dissipation. Moment rotation curves obtained from cyclic loading tests have generally shown narrow hysteresis loops representing small energy dissipation. However most of these tests have been at a loading intensity well below maximum. On those occasions when the load was taken close to maximum for the member the hysteresis loops obtained became quite wide representing a reserve of energy dissipation available, if required. At this stage structural damage to the member had occurred. 
(d) Behaviour Under Earthquakes. Most structures containing prestressed elements which have been subjected to earthquakes have performed well. Failures which have occurred appear to have been due mainly to failure of the supporting structure or of joint connections. However there is relatively little information on the behaviour of fully framed prestressed structures under earthquakes.

(e) Joint Details. The importance of joint details has been emphasised by failures in earthquakes. However research on this subject has been relatively neglected.

(f) Response. It is generally accepted that because of damping and energy dissipation considerations the response of a prestressed concrete structure to earthquake loading will be greater than that of a comparable reinforced concrete structure. A dynamic computer analysis of a prestressed frame building verified this, while showing that local plastic hinge rotation requirements were considerably less than that of the comparable reinforced structure. More research needs to be done in this area. It appears that it may be possible to design prestressed concrete structures for smaller structural damage than for reinforced concrete structures, while anticipating greater damage to non-structural elements or special considerations to prevent such damage.

(g) Design. Concern has been expressed that the traditional seismic design methods using equivalent static load may not be applicable to prestressed concrete because of the assumption implicit in them, that energy dissipation is available to reduce the response. In general design codes do not appear to take any increased response of prestressed concrete into account. Where dynamic analysis is not possible recommendations favour an ultimate strength approach to design based on equivalent lateral loads, but advocate caution at this stage by the choice of high load factors for the seismic part of the loading.

\section{Acknowledgements}

The financial assistance of the New Zealand Portland Cement Association and the Ministry of Works is gratefully acknowledged.

The work described in this paper forms part of that executed in the Department of Civil Engineering of the University of Canterbury by the first named author during postgraduate studies supervised by the second and third named authors. 


\section{List of References}

(1) Abeles, P.W., Brown, E.I., Morrow, J.W.: "Development and Distribution of Cracks in Rectangular Prestressed Beams During Static and Fatigue Loading" Journal of the Prestressed Concrete Institute. V.13, No.5, October 1968.

(2) Allardice, N.W.: "Engineering Aspects of the Arts and Library Building, Victoria University of Wellington", New Zealand Engineering, Vol.21, No.12, December 1966.

(3) Antunes, L.: "Le scosse sismiche en le strattura degli edifici". (Seismic shocks and building structures). L'Industria Italiano del Cemento, Vol.36, No.7, July 1966, pp.707-726 (Summaries in French, English, and German).

(4) Ban, S. : "Rigid Building Frames of Post-Tensioned Prestressed Concrete in Active Earthquake", World Conference on Prestressed Concrete, San Francisco, California, July 1957, Proceedings, pp. A22-1 to A22-4.

(5) Base, E.D., and Read, J.B.: "The Effectiveness of Helical Binding in the Compression Zone of Beams", Journal of the American Concrete Institute, Proc. V.62, No.7, p. 763, July 1965.

(6) Bate, S.C.C.: "A Comparison Between Prestressed and Reinforced Concrete Beams Under Repeated Loading". Proceedings Inst. of Civ. Eng., v.24, pp. 331-358, March 1963.

(7) Berg. G.V.: "The Skopje, Yugoslavia Earthquake". American Iron and Steel Institute, 1964, p.41.

(8) Bikhovsky, V.A., Goldenblat, J.I., and Korchynski, J.L. "Design of Earthquake-Proof Building Structures in the U.S.S.R.", Proceedings of the Second World Conference on Earthquake Engineering, vol.III, p. 1743.

(9) Blume, J.A.,: "A Reserve Energy Technique for the Earthquake Design and Rating of Structures in the Inelastic Range". Proceedings of the 2nd World Conference on Earthquake Engineering, Vol.II, p.1061.

(10) Brisac, M,: "Les hangars du Piree: un'ouvrage anti-sismique en beton precontraint" (The sheds in Piraeus (Greece): an earthquake-proof building in prestressed concrete). Construction, v.22, n.3, March 196\%, pp.108-110. In French. 
(11) Despeyroux, J.: "The Agadir Earthquake of February 29th 1960. Behaviour of Modern Buildings During the Earthquake". Proceedings of the 2 nd World Conference on Earthquake Engineering, Japan, 1960. Vol.I, p. 589 .

(12) Despeyroux, J.: "On Use of Prestressed Concrete in Earthquake Resistant Design". Proceedings of the 3rd World Conference on Earthquake Engineering. Vol.III, p.IV-203.

(13) Eastwood, W. and Rao, R.M.: "Fatique Tests on Lee-McCall Prestressed Concrete Beams". Civil Engineering and Public Works Review, Vol.52, No.613, July 1957.

(14) Ellison, W.H., Iin, T.Y.: "Parking Garage Built for $\$ 5.38$ per sq.ft.". Civ.Eng.(NY), v.25, n.6, June 1955, p. 37 .

(15) Entrican, G.C.: "Reinforced Concrete Frames with Prestress. Behaviour Under Repeated Reversed Loading Beyond the Yield". Private Publication. New Zealand, March 1969.

(16) F.I.P.: "Economical Design of Prestressed Concrete Structures in Japan". Federation Internationale de la Precontrainte, 4 th Congress, Theme 3, Paper 5, 1962, pp.40-54.

(17) F.I.P.-C.E.B.: "Recommendations pratiques Pour le Calcul et L"Execution des Ouvrages en Beton Precontraint" (Practical recommendations for the design and construction of prestressed concrete structures). Comite Europeen du Beton, Bulletin D'Information No.54, March 1966 (in French).

(18) F.I.P. : "General Principles of Earthquake Resistant Design of Prestressed Concrete Structures". Report of the Seismic Commission to V Congress of the Federation Internationale de la Precontrainte, Paris, June 1966.

(19) Fintel, M. : Behaviour of Structures in the Caracas Earthquake". Civil Engineering (U.S.A.), February 1968, pp. 42-46.

(20) Galezewski, S. : "Principles of the Design and Construction of Earthquake Resistant Prestressed Concrete Structures". Paper presented at XI Annual Convention, Prestressed Concrete Institute. Miami, Florida, December 1965. 
(21) Glogau, O.A. : "Ist Chilean Conference on Earthquake Engineering. Building Damage 1960 Chilean Earthquake. Recent Trends in Earthquake Resistant Design". Report on overseas visit, August 1963. Structural Design Office, Ministry of Works, New Zealand.

(22) Guyon, Y.: "Energy Absorption by Prestressed Concrete Beams" . Proceedings of the Third World Conference on Earthquake Engineering. Volume III, p.IV-216.

(23) Guyon, Y. : "First Series of Tests. Comparison of Beams in Reinforced Concrete and Prestressed Concrete subjected to Alternated Loads". Private Publication. 19 October 1967.

(24) Gvozdev, A.A. : "Research on Prestressed Concrete in U.S.S.R. and Neighbouring Countries". Paper presented to the Fifth International Congress of Ia Federation Internationale de la Precontrainte, Paris, June 1966. Le Genie Civil, 15 November 1966 (in French).

Australian Building Science and Technology, v.7, n.1, January 1967.

(25) Hognestad, E. : "Research on Prestressed Concrete Outside of Europe and U.S.S.R.". Paper presented to the Fifth International Congress of La Federation Internationale de la Precontrainte, Paris, June 1966. Le Genie Civil, 15 December 1966 (in French).

Australian Building Science and Technology v.7 n.2 February 1967.

(26) Hunt, D.S.: "A Dynamic Study of Structural Concrete". Thesis presented for the degree of M.E., University of Canterbury, 1966.

(27) Inomata, S.: "A report on the behaviour of structures employing prestressed concrete during Niigata earthquake" . Journal of Japan Prestressed Concrete Engineering Association, Vol.6, No.5, Oct. 1964, pp. 38-42 (in English).

(28) Inomata, S.: "Comparative Study on Behaviour of Prestressed and Reinforced Concrete Beams Subjected to Reversed Loading". Private Publication, Feb. 1969.

(29) Jacobs, M.L.: "The Fatigue of Prestressed Concrete Beams Under Reversed Cyclic Loading". Thesis presented for the degree Ph.D., University of Auckland, 1968. 
(30) James, M.L., Lutes, L.D., Smith, G.M.: "Dynamic Properties of Reinforced and Prestressed Concrete Structural Components". Journal of the American Concrete Institute. Proc. V.61, No.11, November 1964, pp. 1359-1382.

(31) Kaldjian, M.J., Tan, W.R.J.: "Earthquake Response of RambergOsgood Structure", ASCE Proc. V.94 (Journal of Structural Division) n St.10, Oct.1968, paper 6196, pp.2451-65.

(32) Korchinskii, I.L.: "Predvaritel 'no napryazhennyi zhelezobeton", (Prestressed reinforced concrete in earthquake resistant construction). Beton, Zhelezobeton n.1, Jan. 1965, pp.13-16 (in Russian).

(33) Kunze, W.E., Sbarounis, J.A., Amrhein, J.A. "Behaviour of Prestressed Concrete Structures During the Alaskan Earthquake". Journal of the Prestressed Concrete Institute, V.10, No.2, April 1965.

(34) Leonhardt, F.: "Prestressed Concrete" pp. 645-664, Berlin, W. Ernst, 1964.

(35) Ligtenberg, M.F.K.: "Research on Prestressed Concrete in Eastern Europe". Paper presented to the Fifth International Congress of La Federation Internationale de la Precontrainte, Paris, June 1966. La Genie Civil, Tome 143, No.22, 15 Nov.'66, pp. 472 .

(36) Lin, T.Y.: "Strength of Continuous Prestressed Concrete Beams Under Static and Repeated Loads". Journal of the American Concrete Institute, Vol.26, n.10, June 1955, pp.1037-1060.

(37) Lin, T.Y.: "Revolution in Concrete". N.Z. Concrete Construction 6(9): pp.156-159, September 1962.

(38) Lin, T.Y.: "Design of Prestressed Concrete Buildings for Earthquake Resistance". Journal of the Prestressed Concrete Institute, v.9, No.6, Dec.1964,pp.15-31. Proc. ASCE, vol.91, No.St5, Oct.1965,pp.1-17.

(39) Medearis, K and Young, D.H.: "Energy Absorption of Structures Under Cyclic Loading". Proceedings ASCE, V.90, No.ST1, Pt.1, p.61, Feb. 1964.

(40) Muto, K.: "Prestressed Concrete Structures in Earthquake Regions". Journal of the American Concrete Institute, No.7, V.64, July 1967.

(41) Nakano, K.: "Experiments on the Behaviour Under Lateral Force of Prestressed Concrete Portal Frames". Transactions of Japan Architectural Institute No. 102, September 1964 (in Japanese). 
Occasional Report No.21 of Building Research Institute, Japan, 1964 (in English).

(42) Nakano, K.: "Experiment on Behaviour of Prestressed Concrete Four Storeyed Model Structure Under Lateral Force". Transactions of Japan Architectural Institute, November 1964 (in Japanese).

Proceedings 3rd World Conference on Earthquake Engineering, Vol.III, p.IV-572.

(43) Nakano, K.: "Study on Load-Deflection Characteristics of Prestressed Concrete Structures". Occasional Report No.24 of Building Research Institute, Japan. July 1965 (in English).

(44) Nordby, G.M. and Venuti, W.J.: "Fatigue and Static Tests of Steel Strand Prestressed Beams of Expanded Shale Concrete and Conventional Concrete". ACI Journal, Proc. V.54, August 1957.

(45) Oladapo, I.O.: "Dynamic Loading of Prestressed Concrete Beams". Magazine of Concrete Research, Vol.14, No.40, March, 1962.

(46) Oladapo, I.O.: "Rate of Loading Effect on Moment-Curvature Relation in Prestressed Concrete Beams". ACI Journal, Proc.V.61, No.7, July 1964.

(47) Ozell, A.M., and Ardaman, E.: "Fatigue Tests of Pre-tensioned Prestressed Beams". ACI Journal, Proc. V.28, No.4, October 1956.

(48) Penzien, J.: "Damping Characteristics of Prestressed Concrete". Report to U.S. Naval Civil Engineering Laboratory. University of California, January 1962.

ACI Journal, Proc.V.61, No.9, September 1964.

(49) Rosenbleuth, E.: Discussion on paper by T.Y. Iin "Design of Prestressed Concrete Buildings for Earthquake Resistance". Journal of the Structural Division, Proceeding of the ASCE, Vol.92, No.ST1, Feb.1966.

(50) Rosenbleuth, E.: "On Earthquake Resistant Design". New Zealand Engineering, Vol.21,No.9, 15 September 1966.

(51) Sinha, B.P., Gerstle, K.H., and Tulin, L.G.: "Stress-Strain Relations for Concrete Under Cyclic Loading". ACI Journal, Vol.61, Feb. 1964.

(52) Spencer, R.A.: "The Damping and Flexural Properties of Prestressed Concrete Members Subjected to Reversed Cyclic Loading". Thesis presented for degree Ph.D., University of Auckland, 1966. 
(53) Spencer, R.A.: "Stiffness and Damping of Cyclically Loaded Prestressed Concrete Members". Paper presented to 2nd Congress Nacional De Ingeniera Sismica Veracruz, Ver. May 1-4 1968.

(54) Spencer, R.A.: "The Nonlinear Response of Some Multistorey Reinforced and Prestressed Concrete Structures Subjected to Earthquake Excitation". A report on research conducted at California Institute of Technology, November 1968.

Paper presented to 4 th World Conference on Earthquake Engineering, Santiago, Jan. 1969.

(55) Spooner, B.W. and Norman, R.G.: "Development of Prestressed Concrete in New Zealand by the Ministry of Works". Proceedings World Conference on Prestressed Concrete, San Francisco, July 1957.

(56) Sutherland, W.M.: "Prestressed Concrete Earthquake Resistant Structures - Development, Performance, and Current Research". Proceedings of 3rd World Conference on Earthquake Engineering, Vol.III, p.IV -463 .

(57) Tanabashi, R.: "Nonlinear Transient Vibration of Structures" Proceedings of 2nd World Conference on Earthquake Engineering, Vol.II, p.1223.

(58) Thomaides, S.S.: "Earthquake Response of Systems with Bilinear Hysteresis". Proc. ASCE, V.90, No.ST4, Pt. August 1964.

(59) Trott, J.J. and Fox, E.R.: "Comparison of the behaviour of concrete beams under static and dynamic loading". Magazine of Concrete Research, Vol.11, No.31, March 1959.

(60) Venuti, W.J.: "A Statistical Approach to the Analysis of Fatigue of Prestressed Concrete Beams". ACI Journal, Proc. Vol.62, No.11, Nov. 1965.

(61) Williamson, K.: "Prestressed Concrete Seismic Design". Proceedings of Seminar 'Seismic Problems in Structural Engineering', University of Canterbury, New Zealand.

(62) Zavriev, K.S.: "Dynamics and Earthquake Resistance of Prestressed Reinforced Concrete Structures". Proceedings of 3rd World Conference on Earthquake Engineering, New Zealand 1965. Vol.II, p.IV -645 .

"ACI Standard Building Code Requirements for Reinforced Concrete". Chapter 26, Prestressed Concrete (ACI 318-63). 
"Seismic Design Recommendations for Prestressed Concrete". New Zealand Prestressed Concrete Institute, September 1966.

"Principles of the Design and Construction of Earthquake Resistant Prestressed Concrete Structures". Journal of PCI, Vol.II, No.3, June 1966.

"Prestressed I-Shaped Wall Aids 9-Story Garage to Resist "Quakes". Engineering News Record, V. 154, n.13, March 31, 1955, pp. 39-40.

"Engineers Report on Seismic Damage" (Skopje Earthquake), Engineering News-Record. Vol.171, No.16, 17 October 1963, pp.36-38.

"This paper was first presented to the annual conference of the New Zealand Prestressed Concrete Institute at Wairakei in October 1969" 